\title{
Application of Cloud Computing at KTU: MS Live@Edu Case
}

\author{
Regina MISEVIČIENE ${ }^{1}$, Germanas BUDNIKAS ${ }^{1}$, \\ Danutė AMBRAZIENE் ${ }^{2}$ \\ ${ }^{1}$ Business Informatics Department, Kaunas University of Technology \\ Studentu 56-442, Kaunas, Lithuania \\ ${ }^{2}$ Faculty Service Division, Institute of Information Technology Development \\ Studentu 48a, Kaunas, Lithuania \\ e-mail: \{regina.miseviciene,germanas.budnikas,danute.ambraziene\}@ktu.lt
}

Received: September 2011

\begin{abstract}
Cloud computing is a significant alternative in today's educational perspective. The technology gives the students and teachers the opportunity to quickly access various application platforms and resources through the web pages on-demand. Unfortunately, not all educational institutions often have an ability to take full advantages of the newest information technology. The paper analyzes possibilities of the cloud computing technology that can help educational institutions to support the process of teaching and learning.

There is also presented a cloud computing technology based solution introducing the MS Live@Edu environment as a means of communication and collaboration between lecturers and students. The authors have a successful experience of using MS Live@Edu during 3 academic years for delivering about 10 unique courses for approximately 700 students in Kaunas University of Technology (KTU). The use of MS Live@Edu environment for educational purposes is summarized by explaining the advantages of cloud computing gained both by lecturers and students.
\end{abstract}

Keywords: education, social networking, cloud computing, web-based learning, MS Live@Edu.

\section{Introduction}

Educational institutions have become dependent on the information technologies (IT) to support skill providing to the students. Schools often lack the resources or ability to take full advantage of information technology. One of the newest technologies in IT world is cloud computing that has a significant impact on teaching and learning. The cloud computing technology offers a way to expand the accessibility of education, particularly in remote and underserved communities. Students and teachers have the opportunity to quickly access various application platforms and resources through the web pages ondemand. The access can be provided through virtual classrooms, with students attending classes in their own homes on their own computers, with the teacher being present hundreds of kilometers away (Sourya, 2011). Many schools are already moving in this direction. 
Unfortunately, not all educational institutions often have ability to take full advantage of the newest information technology that supports teaching and learning: many of the schools do not have sufficient hardware and/or software to give the students a complete learning experience.

Considering the before mentioned reasons, the aim of the paper is to analyze possibilities of the cloud computing technology that can help educational institutions to support a process of teaching and learning.

To achieve this aim, the following research tasks are fulfilled:

- the exploration of cloud computing possibilities for the education organizations;

- the detection of the benefits and risks that the educational institutions can get;

- the performance of a case study how the cloud computing benefits are being applied at Kaunas University of Technology.

The research was carried out by reviewing and summarizing the most recent publications and applying up-to-date solutions in this field.

In the next sections the paper deals with the investigation of the cloud computing technology benefits for education, analysis of the cloud infrastructure at Kaunas University of Technology and a case study of cloud computing application in IT courses.

\section{Using Cloud Computing Technology in Education}

Cloud computing technology is a way to provide computer applications to users without the need to purchase, install, or support software on their local computers and/or servers. Educational institutions are beginning to take the advantages of existing applications hosted on a 'cloud'.

Today the cloud based platforms provide no cost services (Jones and Sclater, 2009) to educational institutions like mail, messaging and collaboration tools (e-mail, contacts, and calendars), office applications (document storage, creation and sharing documents) and platform applications (the ability to create websites or learning management systems).

The newest technology offers many benefits to the educational organizations (Jones and Sclater, 2009):

- it releases the institutions from data management, ensures that the users always have the newest documents and reduces the requirements and costs associated with data security;

- it offers a range of online tools and services that provide secure communication and collaboration capabilities;

- it lets both the teachers and the students to access, share and publish documents, class calendars or web pages.

Cloud computing is a significant alternative for today's educational environment. Advantages that come with the newest technology can help resolve some of the common challenges. The papers of many authors (Al-Zoube, 2009; Cloud ..., 2010; Schools, 
2010; Jones and Sclater, 2010; Sourya, 2011; Tuncay, 2010) mark the advantages of the cloud computing technology for the educational sector. Along with the advantages in the educational institutions researchers disclosed some risks.

We summarized the references and presented only their main characteristics (Table 1).

Unfortunately, not all educational organizations often use the newest information technologies. By the investigation of Gartner (Bittman, 2009) it can be seen that cloud computing is being used widely in the areas of finance and business while it is compara-

Table 1

Characteristics of advantages and risks

\begin{tabular}{|c|c|}
\hline Advantages & Explanations \\
\hline $\begin{array}{l}\text { Learning } \\
\text { environment }\end{array}$ & $\begin{array}{l}+ \text { Providers offer email services with long-term e-mail addresses and other appli- } \\
\text { cations that they can use to collaborate and communicate online; } \\
+ \text { Educational environments contain collaboration tools such as messaging, calen- } \\
\text { dar and contact management opportunities for communication and collaboration; } \\
+ \text { They offer also document creation applications with word processing, spread- } \\
\text { sheets and presentations. These documents can all be edited collaboratively with } \\
\text { other users through the Internet. }\end{array}$ \\
\hline
\end{tabular}

- Transferring data to a third party for hosting in a remote data centre, not

- Institutions are afraid that remote connections might pose security threats to them and to their company;

- Institution data is at the mercy of a third-party company

Institution IT + Cloud computing allows energy efficient centralization of infrastructures and helps to reduce IT costs;

+ Online tools help the protect itself from spam and malware;

+ Servers provide software applications, operating the systems through the Internet access, rather than having them installed and maintained on each platform separately;

+ Educational institutions are also beginning to use the lower level of cloud services for purposes such as data storage. This may be attractive where videos and audios are provided as open educational resources.

- Institutions often do not have control over the remote servers, their software, Control loss or their security;

- Providers will supply the users with undesirable advertising.

\begin{tabular}{|c|c|}
\hline Accessibility & $\begin{array}{l}+ \text { Web-based applications are accessible with a variety of computer and mobile } \\
\text { platforms, making these tools available anywhere the Internet can be accessed; } \\
+ \text { Many applications (such as word processing, spreadsheets, presentations, } \\
\text { databases, etc.) can be accessed from a web browser; } \\
+ \text { Students can work on the cloud, cooperate with team members and share data. }\end{array}$ \\
\hline \multicolumn{2}{|c|}{$\begin{array}{l}\text { The institution will become dependent on the products of a particular } \\
\text { provider; } \\
\text { - It is significantly difficult to migrate from any widely used system. }\end{array}$} \\
\hline
\end{tabular}


tively rarely used at educational institutions.

\section{Cloud Based Education in Lithuania}

Nowadays more attention in Lithuania is devoted to the integration of information technologies into the process of education in order to get better results of studies (Nekrašaite and Petkus, 2010; Dagienè and Kurilovas, 2010). Educational institutions make an effort to find the best methodologies for making web-based learning more effective. Different forms of web-based learning such as multimedia $\mathrm{CD}$, distance study courses, interactive entertainment activities, etc., are proposed to the learners (Tankelevičienè, 2011).

There is also communication software (Brazdeikis, 2010; Gudonienè et al., 2010) designed for education institutions in Lithuanian market:

- virtual environment (Moodle, Elgg, Atutor, WebCT),

- intranet (First Class, Antri namai),

- content management systems (Wordpress, Joomla).

Unfortunately, not all educational institutions often have the ability to take full advantage of web-based learning having only strongly limited amount of resources (Tankelevičienè, 2011).

Cloud based technologies such as social network tools (Gmail/google groups, Live@edu, Facebook, Yahoo) can solve the problems (Šidlauskas and Vitkutè-Adžgauskienè, 2009; Budnikas and Misevičiené, 2010). Social networking is possible in person, especially in the workplace, universities, and high schools, but it is most popular online. This is because unlike most high schools, colleges, or workplaces, the internet is filled with millions of individuals who are looking to meet people, to gather and share firsthand information or to find employment. Social network for teachers will provide open educational resources and tools available and accessible to all students. The environment can be used by teachers, pupils and students to learn and work together (Gudoniene et al., 2010).

In this section we compare only cloud computing based Google or Microsoft services that providers use free of charge for educational purposes in Lithuania.

Students and teachers often use cloud computing services provided by Google or Microsoft companies. Microsoft and Google are in hot competition as the main rivals. Both companies are happy to give educational institutions free cloud email and collaboration services. Both Google and Microsoft offer free of charge email services to the educational sector in many countries. Google Apps for Education and Microsoft Live@edu contain other communication tools such as instant messaging along with contact management and calendar software. Also there are document creation applications allowing the production of word processed documents, spreadsheets and presentations as well as the ability to create websites. These can all be collaboratively edited with other users. Significant storage space for documents of all types is offered to the users (Sclater, 2010). One of the latest additions of these tools is a free plug-in for the Moodle learning management system, providing access to many of the Live@edu services. 
Table 2

Google Apps vs. Microsoft Live@Edu for Education

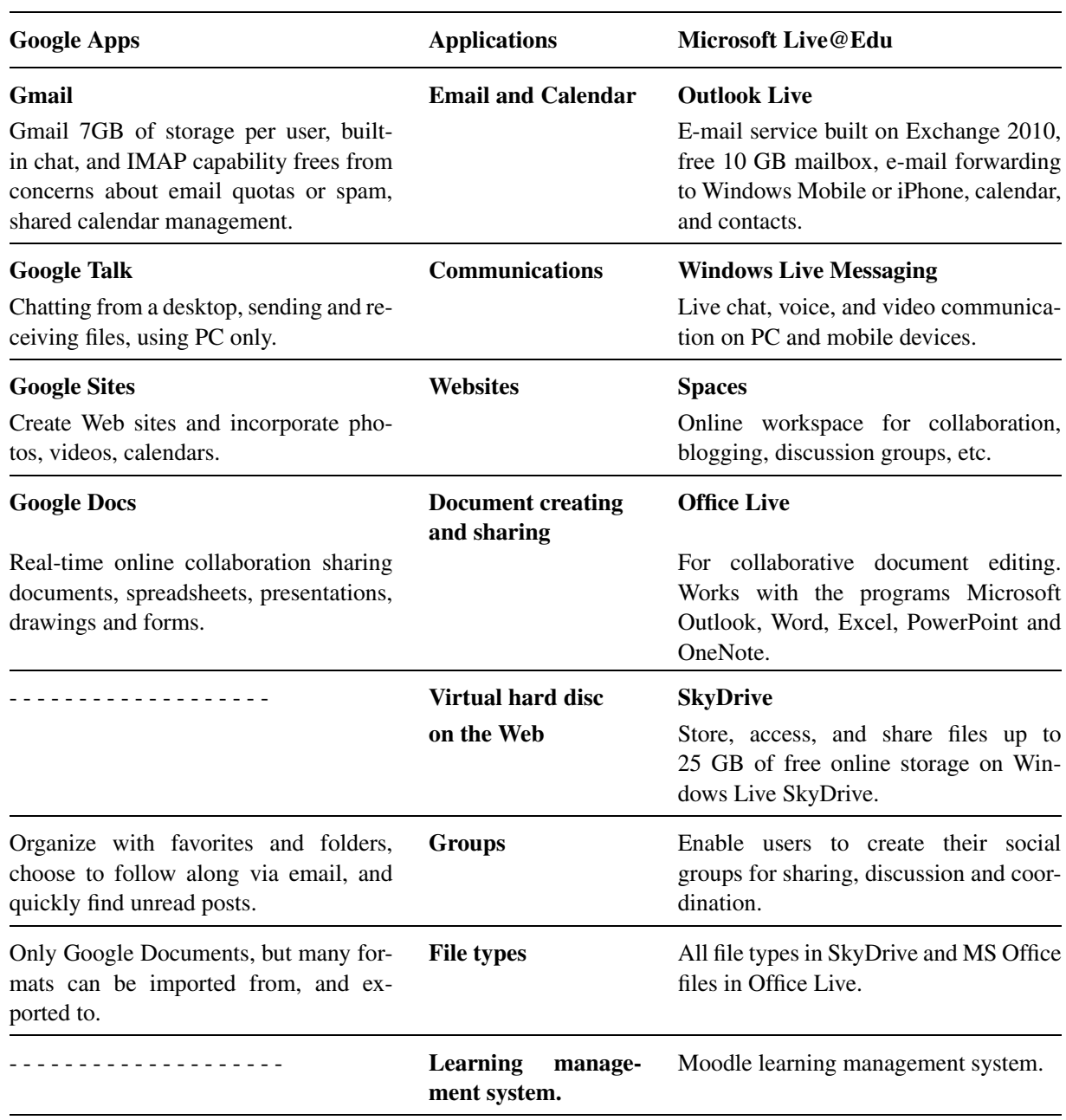

Table 2 lists some of the differences between Live@Edu and Google Apps for collaboration applications, document storing and sharing based on internet publications (Choosing ..., 2011; Google ..., 2011; IT . .., 2011; Keir, 2011; Prepare . .., 2011).

Kaunas University of Technology (KTU) has made choice based on Microsoft Live@Edu for their needs, because of their offerings and the familiarity of the Office applications.

The next sections deal with the usage of Microsoft Live@Edu environment at Kaunas University of Technology. 


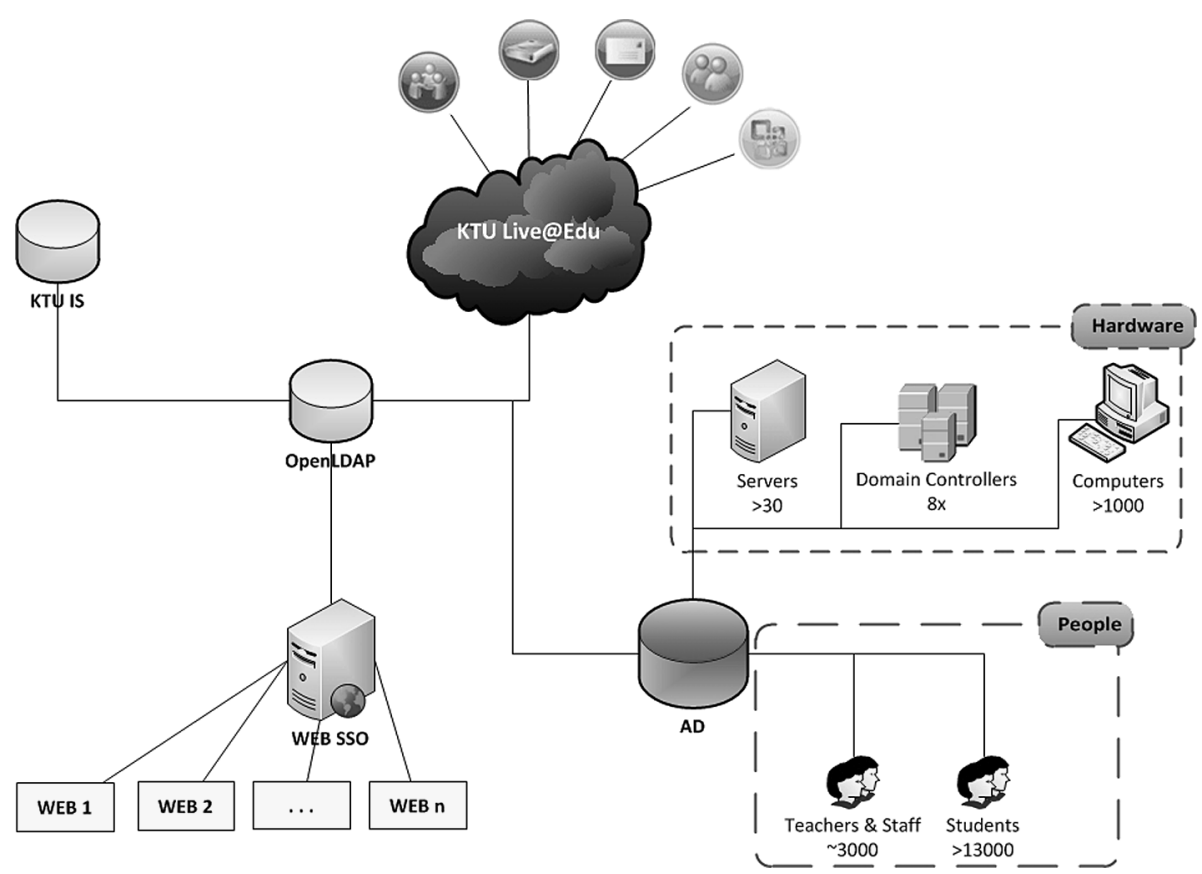

Fig. 1. Infrastructure of cloud computing technique of Kaunas University of Technology (source: created by the authors).

\section{Cloud Infrastructure at Kaunas University of Technology}

IT infrastructure of Kaunas University of Technology is showed in Fig. 1. Central part of the infrastructure is Information system of Kaunas University of Technology (KTU IS). The system consists of many parts like University e-mail system, Academic Information System, Library information systems, e-learning systems (like Moodle), etc.

One of the most recent services IT department of KTU provides is Microsoft Live@Edu cloud service. Students and teachers can use @ktu.edu e-mail service (running on Microsoft Exchange). Both teachers and students can also use other services available in Live@Edu, such as cloud storage of 25GB, data synchronization, instant messaging and Microsoft Office applications (Word, Excel, PowerPoint, and OneNote) in the browser. The services are integrated with OpenLDAP. The directory synchronizes people data with academic information system. It lets also automatically limit the access of the students that have already graduated or left the university. The teachers do not have to worry about the students accessing computers in the classrooms. In addition, both students and staff members are able to change their password easily without contacting IT helpdesk.

To use IT environments in the university more effectively, IT department uses Active Directory (AD). The Active Directory domain contains information about both hardware resources (computers, workstations, printers) and people (students, teachers). Resources are grouped to Organizational Units in accordance with the university and security re- 
quirements. Administrators can assign settings (Group Policy Objects) to specific classes or users only. Group Policy also simplifies update of operating systems, software installation, and user profile management, etc. In total, there are about 1000 computers and 20000 users in the current Active Directory domain.

To improve user authentication process even more, the web single sign-on (SSO) service is used. This service allows the developer of each university web site to integrate user authentication with already existing OpenLDAP directory. Therefore, site owners do not need to take care of users' management. At the same time users are able to use the credentials they already have to login to newly created university sites.

IT administrators regularly update IT infrastructure and create new services to make computer usage, administration and e-learning painless both for students and staff.

\section{Case Study: Using MS Live@Edu at KTU}

Apart from MS Live@Edu environment that is successfully being used by paper authors at KTU during 3 years, two educational environments are widely spread at KTU. They are Moodle environment (Kazarinas et al., 2010) and Joomla extension module for education (Brazdeikis, 2010). Internet portal moodle.ktu.lt states that more than 8100 users use KTU Moodle and 219 courses are prepared for this environment. Moodle is an Open Source Course Management System, also known as a Learning Management System or a Virtual Learning Environment (VLE; Henrick et al., 2011). The system is an education oriented environment containing specialized course management features like assignment module, choice module, glossary module, etc. (Moodle, 2011) to support learning process. In spite of wide usage of the Moodle VLE, some difficulties still exist. Saugennienè (2010) indicates some problems of Moodle e-study environment acceptation by lecturers and students. They are (a) insufficient students' willingness to use the environment and (b) heaviness for both students and lecturers to master Moodle environment. The reason of this could be an occasional usage of the environment - only as needed for educational purposes. In this turn, we suppose that the environments where students actively communicate and collaborate should be used instead. This idea is also emphasized in a literature: "social communication is an important aspect of learning" (Rennie and Morrison, 2008); "educational institutions may need to utilize existing social network applications such as Facebook for education" (Tian et al., 2011), etc.

Following this, paper authors have applied MS Live@Edu solution, as a social networking tool for education, for a ten IT-based courses for approximately 700 students at our university. We consider the educational solution as an interaction of functions that teachers and students can perform. We group these functions into two general categories course participant functions (see Fig. 2) and course group functions (see Fig. 3). Let's consider the mentioned functions in detail.

A course participant category describes actions, which course participant can undertake. In Fig. 2, a course participant functions are depicted. They are customization features, planning \& communication, documenting using an integrated office and file storage and sharing. 


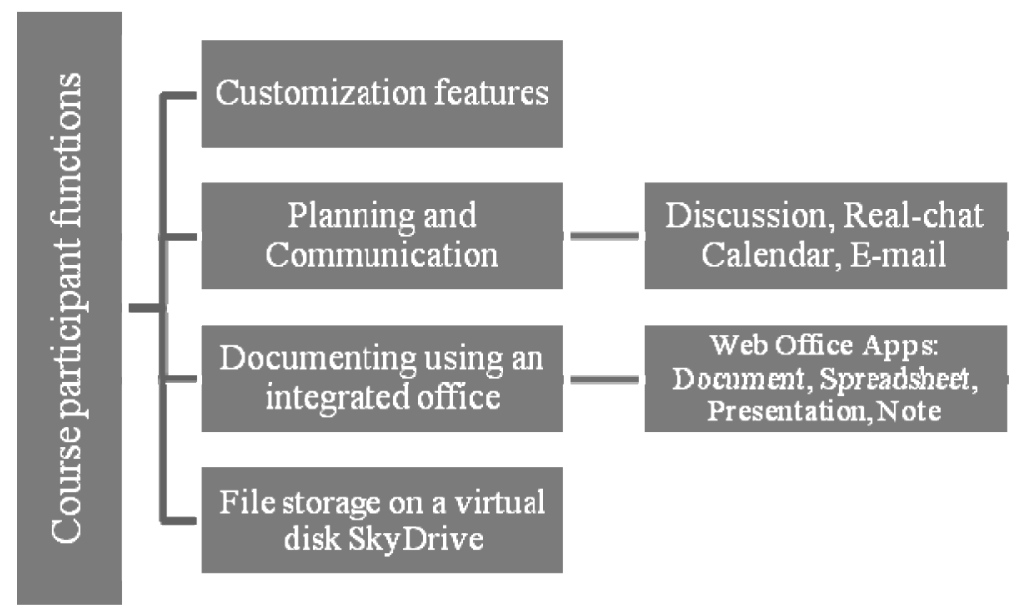

Fig. 2.MS Live@Edu course group functions.

A course group is understood as a set of features for course delivery including a management of the course participants. The course group category is characterized by membership administration, planning \& communication and file storage on a virtual disk SkyDrive functions (see Fig. 3). Basic instances of SkyDrive usage include storage of various documents like slides, assignments, student works, etc. Planning \& communication function is responsible for discussion, real-chat and calendar, and E-mailing. While membership management covers user authentication, enrolment to a course and user type management.

Notice that file storage and planning \& communication functions are characteristic for course group and course participant categories both.

Functions depicted in Figs. 2 and 3 are being successfully used during usual and extended educational programs, which are tightly related to these types of learning: e-Learning and a blended learning. The last one is a mix of e-Learning and a face-toface learning (Rennie and Morrison, 2008). The following table explains gained benefits from using the educational solution with respect to the type of learning (see Table 3).

Along with the benefits from the application of MS Live@Edu some limitations listed in (Mircea and Andreescu, 2011) take place. They are "not all applications run in cloud, security and protection of sensitive data, speed/lack of Internet can affect work." However, based on a recent review, Lithuania has the internet of a leading quality (Budnikas, 2010), thus possible disruption or a restricted use can occur due to the throughput limitation of local network hardware (e.g. when a group of students view tutoring video).

To determine a usability of the environment we have accomplished a review asking both involved lecturers (number of replies is 6) and students (number of replies is approximately 700; type of study programs - usual and extended) about an importance of a certain feature of MS Live @Edu ( 0 - not used, 100\% is very important) during the course and after the course. Figure 4 depicts the results. 


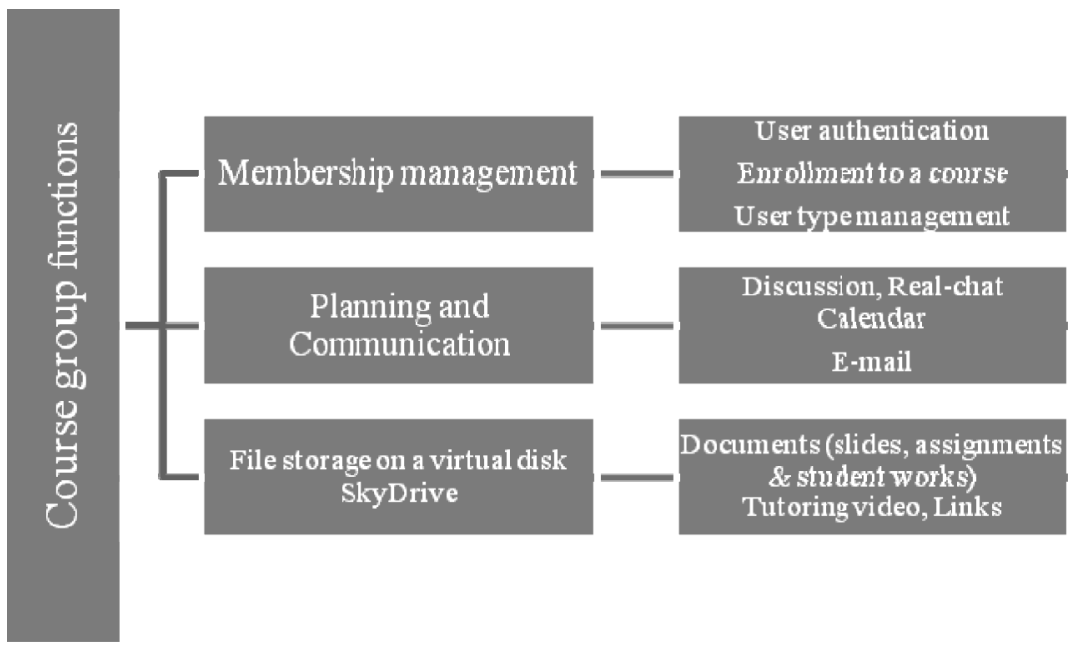

Fig. 3. MS Live@Edu course participant functions.

The accomplished review helped us to understand an acceptance level of the social network for education MS Live@Edu in general and its specific features in detail by KTU users - both students and teachers. The most important property is - the environment is being actively used after a finishing the course. Using Fig. 4 we can see that the most important features for both students and lecturers are virtual disk - SkyDrive for personal and course needs, ability to collaborate while working with shared documents using the integrated office applications and social networking.

Table 3

Benefits of MS Live@Edu with respect to types of learning

\begin{tabular}{ll}
\hline Type of learning & Benefits of MS Live@Edu usage \\
\hline e-Learning & - Remote students use course SkyDrive for storing their accomplished assign- \\
ments; & - Real-time chat is used by teachers for consulting remote students; \\
- Web Office Applications are used for consultations while both teacher and stu- & dent edit the same document and the teacher is able to advice in a real time. \\
Blended learning & - Students enrolled to a course have access to a courseware that is stored in a \\
& course virtual disk; \\
- & Discussions are actively used for communication between students and teachers; \\
- Real-time chats are used for communications; \\
- Calendars and E-mail are actively used for time planning and scheduling; \\
- Profile customization features and social communication make education envi- \\
ronment more users friendly that assists in learning; \\
- Teacher uses course virtual drive and integrated Web Office Applications for \\
- delivering lectures. All related material is stored in one place; \\
- Students and teachers access their files from personal virtual drives as at labs, as \\
at home or other places. No portable media is needed.
\end{tabular}




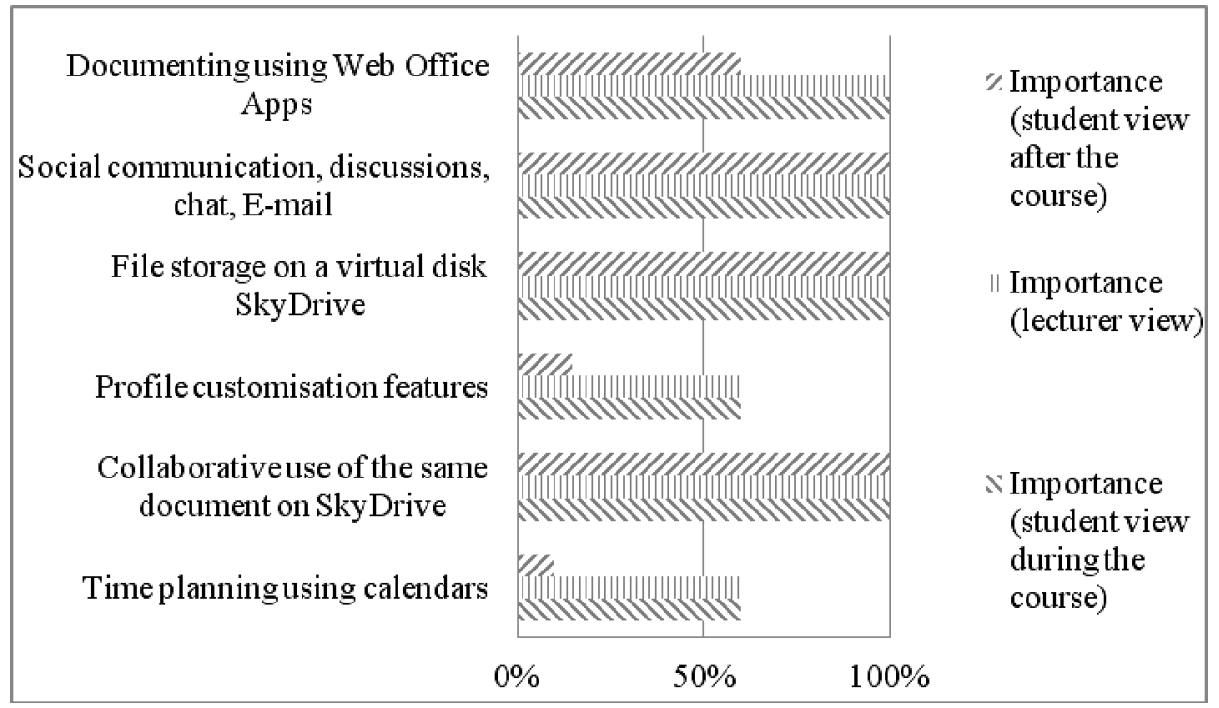

Fig. 4. An importance of a certain feature of MS Live@Edu with respect to type of user.

\section{Evaluation and Conclusions}

Cloud computing is a significant alternative today's educational perspective. The technology gives the students and teachers the opportunity to quickly access various application platforms and resources through the web pages on-demand. Unfortunately, not all educational institutions often have an ability to take full advantage of newest information technology that supports teaching and learning: many of the schools do not have sufficient hardware and/or software. The research in the paper verified that cloud computing technologies can help the schools to solve many of problems and improve the educational process.

Both Google and Microsoft offer free of charge email services to the educational sector in many countries like e-mail, messaging and collaboration tools, office applications (document storage, creation and sharing documents) and the ability to create websites or learning management systems.

Successful practice of using MS Live@Edu during 3 academic years for delivering about 10 unique courses for approximately 700 students showed a wide variety of advantages of cloud computing it gives both for lecturers and for students. The accomplished review helped us to understand an acceptance level of the social network for education MS Live@Edu in general and its specific features in detail by KTU users - both students and teachers.

Case study showed a usability of the MS Live@Edu environment while applying it during e- and blended learning as well as after its finishing. The most important features identified are social communication, collaborative processing of documenting using the integrated office and file storage and sharing. All these features are accessible 24/7 via Internet. 


\section{References}

Al-Zoube, M. (2009). E-Learning on the Cloud.

http: / / www. scribd.com/doc/36527367 / E-Learning-on-the-Cloud.

Bitman, T. (2009). Cloud Computing Inquiries at Gartner.

http: / /blogs.gartner.com/thomas_bittman/2009/10/29/cloud-computinginquiries-at-gartner/.

Brazdeikis, V. (2010). Švietimo informacinių sistemų integracija. E-Education: Science, Study and Busines. In: Proceedings of 3rd International Conference on Advanced Learning Technologies and Applications, 12-19.

Budnikas, G. (2010). Kodèl lietuviškas internetas kokybiškiausias? Naujoji komunikacija, 1, 56-57 (in Lithuanian).

Budnikas, G., Misevičienè, R. (2010). Use of internet-based facilities in innovative IT course. E-Education: Science, Study and Busines. In: Proceedings of 3rd International Conference on Advanced Learning Technologies and Applications, 138-139.

Choosing between Microsoft's Live@Edu and Google Apps for Education (2011). http: / /www. emergingedtech.com/2009/10/choosing-betweenmicrosoft $\% 2 \% 80 \% 99 s-1$ iveedu-and-google-apps-for-education/.

Cloud computing in education (2010). UNESCO Institute for Information Technologies in Education. http: / / www . microsoft. com/education/solutions/cloudcomputing. aspx.

Dagiene, V., Kurilovas, E. (2010).Web 2.0 Technologies and Applications in the Best Practice Networks and Communities. Informatics in Education, 9(2), 185-197.

Google Apps for Edu (2011). http: / /www. google.com/a/help/intl/en/edu/.

Gudoniene, D., Armalyte, N., Piguleviciene, J. (2010). Web 2.0 technologies in business and education. EEducation: Science, Study and Busines. In: Proceedings of 3rd International Conference on Advanced Learning Technologies and Applications, 119-125.

Henrick, G., Cole, Je., Cole, Ja. (2011). Moodle 2.0 for Business Beginner's Guide.

IT Connect (2011). http: / / www . washington. edu/itconnect/teamwork/cloudfaq. html.

Jones, Ch., Sclater, N. (2010). Learning in an age of digital networks. International Preservation News, 55, 6-10. http: / / oro.open.ac.uk/24116/2/learning_in_an_age.pdf.

Karazinas, E., Kardzys, E., Matulaitis, E. (2010). KTU EMTC Moodle paslaugos. E-Education: Science, Study and Busines. In: Proceedings of 3rd International Conference on Advanced Learning Technologies and Applications, 107-110 (in Lithuanian).

Keir, J. (2011). Investigation into Google Apps and Microsoft's Live@Edu. http: / / ist. uwaterloo.ca/projects/GoogleAppsMicrosoftLive/charter.html.

Mircea, M., Andreescu, A.I. (2011). Using Cloud Computing in Higher Education: A Strategy to Improve Agility in the Current Financial Crisis. Communications of the IBIMA Journal, 2011, Article ID 875547. Internet access:

http: / / www. ibimapublishing. com/journals /CIBIMA/2011/875547/875547.pdf.

Moodle Features (2011). http: / / docs.moodle.org/20/en/Features.

Prepare your students for the future (2011). http: / / www . microsoft. com/liveatedu/.

Rennie, F., Morrison, T. (2008). e-Learning and Social Networking Handbook: Resources for Higher Education. Routledge.

Rutkauskienė, D., Pociūtė, E., Targamadzė A., Strička M. (2006). Lietuvos virtualus universitetas. http: / / distance.ktu. It/livun/.

Saugeniene, N. (2010). E-studies in the traditional higher education institution: teachers ' attitudes, competencies and institutional support for them. Innovative Trends in e-Learning, 52-57.

Schools, IT and Cloud Compiuting. The Agility for 21-st Centuery eLearning (2010). http: / /www . techrepublic.com/whitepapers/schools-it-and-cloud-computingthe-agility-for-21st-century-elearning/2213701.

Sclater, N. (2010). eLearning in the Cloud. International Journal of Virtual and Personal Learning Environments, 1(1), 10-19.

Sessums, Ch.D. (2004). The Distance Education Online Symposium. http: / / lists.psu . edu / cgi-bin/wa?A2 =ind0 $409 \& \mathrm{~L}=$ deos $-1 \& \mathrm{~T}=0 \& \mathrm{~F}=\& \mathrm{~S}=\& \mathrm{P}=8455$.

Sourya, B. (2011). How Can Cloud Computing Help In Education? http: / / www. cloudtweaks. com/2011/02/how-can-cloud-computing-help-ineducation/\#. 
Šidlauskas, K., Vitkutè-Adžgauskienè, D. (2009). Studiju pasiekimu elektroninio portfelio sprendimai socialiniu tinklu aplinkoje. Informacijos mokslai, 50, 124-129.

Tankelevičienė, L., Damaševičius, R. (2009). Characteristics of domain ontologies for web based learning and their application for quality evaluation. Informatics in Education, 8(1), 131-152.

Tian, S.W., Yu, A.Y., Vogel, D., Kwok, R. (2011). The impact of online social networking on learning: a social integration perspective. International Journal of Networking and Virtual Organisations, 8 (3/4), 264-280.

The National Institute of Standards and Technology (2011). http: / / www . ni st.gov/index. html.

Tuncay, E. (2010). Effective use of cloud computing in educational institutions. Procedia Social and Behavioral Sciences, 2, 938-942.

Vaquero, L.M., Rodero-Merino, L., Caceres, J., Linder, M. (2009). A break in the clouds: towards a cloud definition. Computer Communication Review, 39, 50-55.

Zuzevičiūtè V. (2010). E-learning at the university: challenges for the WEB 2.0 generation. E-Education: Science, Study and Busines. In: Proceedings of 3rd International Conference on Advanced Learning Technologies and Applications, 28-38.

R. Misevičienè is an associate professor at Business Informatics Department in Kaunas University of Technology (KTU), Kaunas, Lithuania, where she is teaching information technologies, project management and design of web based systems.

Her research interests mainly include artificial intelligence, formalization of complex systems and integrated analysis using logic programming, verification of knowledge base systems and research of problems in educational e-learning systems and distance study. She prepared more than 40 scientific publications in Lithuania and foreign journals and conference proceedings.

G. Budnikas defended his doctoral thesis in 2004 in the field of informatics (physical sciences). Now he is an associate professor at Business Informatics Department in Kaunas University of Technology (KTU), Kaunas, Lithuania. His current scientific interests include formal specifications, knowledge engineering, static and dynamic analysis and cloud computing.

D. Ambrazienè is a chief of Faculty Service Division at a Computer Service Centre at Institute of Information Technology Development. D. Ambraziene is a member of a national distance teaching association. Her interests include use of virtual IT infrastructure in study process.

\section{Debesu kompiuterijos panaudojimas KTU: MS Live@Edu aplinkoje Regina MISEVIČIENĖ, Germanas BUDNIKAS, Danutè AMBRAZIENĖ}

Debesų kompiuterija yra reikšminga alternatyva šiandienos mokymo įstaigoms. Šiame straipsnyje autoriai nagrinejja kaip debesų kompiuterijos teikiamos paslaugos gali padèti švietimo įstaigoms spręsti daugeli problemų ir pagerinti ugdymo procesą.

Straipsnyje pristatoma debesų kompiuterija grịsta MS Live@edu aplinka, kuri naudojama tiek mokymo medžiagos pateikimui internete tiek ir bendradarbiavimui tarp dèstytojų ir studentų. Ši aplinka suteikia nemokamos bendradarbiavimo paslaugas: el. paštą, diskusijas, failų mainu saugyklą ir laiko planavimą grupèms.

Straipsnio autoriai MS Live@Edu sèkmingai taiko jau nuo atsiradimo Lietuvoje 2009 metais daugiau nei 10-tyje unikalių kursu maždaug 700 studentų. MS Live@edu aplinkos panaudojimo patirtis mokymo tikslams apibendrinta pateikiant debesu kompiuterijos privalumus tiek dėstytojams, tiek studentams. 